\title{
ANALISIS SIFAT FISIKA TANAH GAMBUT PADA HUTAN GAMBUT DI KECAMATAN TAMBANG KABUPATEN KAMPAR PROVINSI RIAU
}

\author{
Analysis of Soil Physical Peat Land in Peat Forests in Tambang Sub-District, \\ Kampar District, Riau Province
}

SUSANDI ${ }^{1}$, OKSANA $^{2}$, DAN AHMAD TAUFIQ ARMINUDIN²

\begin{abstract}
1 Mahasiswa Prodi Agroteknologi Fakultas Pertanian Dan Peternakan UIN Sultan Syarif Kasim Riau 2 Dosen Prodi Agroteknologi Fakultas Pertanian dan Peternakan UIN Sultan Syarif Kasim Riau JL. H.R. Soberantas Km 16 Pekanbaru PO Box 1004, Pekanbaru 28293 Telp.: +62-761-562052, e-mail : oksana_ry@yahoo.co.id
\end{abstract}

\begin{abstract}
The research was conducted on January to April 2013 in the secondary forest Kualu Nenas Village, Tambang District, Kampar Regency, Riau Province. This study was done by observation and survey on $0-50 \mathrm{~cm}, 50-100 \mathrm{~cm}$, and $100-150 \mathrm{~cm}$ of land depth to analysis peat thickness, depth of water table, the colour of peat, peat maturity, bulk dencity, and water content. Results showed that the peat was have more than $6 \mathrm{~m}$ depth. Thickness of water table average was $30.75 \mathrm{~cm}$, soil colour black ground colour reddish, very dull red, and dark brown. The decomposition degree of peat on $0-50 \mathrm{~cm}$ and, $50-100 \mathrm{~cm}$ were hemik (fiber content $41 \%$ and $61 \%$ ), whereas 100-150 cm was fibric (fiber content $70.25 \%$ ). Bulk dencity of $0-50 \mathrm{~cm}, 50-100 \mathrm{~cm}$ and $100-150 \mathrm{~cm}$ depth were $0.15 \mathrm{gr} / \mathrm{cm} 3,0.125$ $\mathrm{gr} / \mathrm{cm} 3$, and $0.105 \mathrm{gr} / \mathrm{cm} 3$. Water content of $0-50 \mathrm{~cm}, 50-100 \mathrm{~cm}$, and $100-150$ depth were $541.82 \%$, $719.41 \%$, and $888.30 \%$.
\end{abstract}

Keywords: Peat land, soil physical, secondary forests.

\section{PENDAHULUAN}

Hutan dan vegetasinya memiliki peranan penting dalam pembentukan dan pemantapan agregat tanah. Vegetasinya berperan sebagai pemantap agregat tanah karena akar-akarnya dapat mengikat partikelpartikel tanah dan juga mampu menahan daya tumbuk butir-butir air hujan secara langsung ke permukaan tanah sehingga penghancuran tanah dapat dicegah. Selain itu seresah yang berasal dari daun-daunnya dapat meningkatkan kandungan bahan organik tanah. Hal inilah yang dapat mengakibatkan perbaikan terhadap sifat fisik tanah, yaitu pembentukan struktur tanah yang baik maupun peningkatan porositas yang dapat meningkatkan perkolasi sehingga memperkecil erosi tanah (Arifin, 2010).

Hutan gambut adalah jenis hutan yang tumbuh pada suatu lapisan tebal dari bahan organik dengan tebal $\pm 50 \mathrm{~cm}$. Lapisan bahan organik ini terdiri atas tumbukan tumbuhan yang telah mati seperti dedaunan, akar-akar, ranting, bahkan batang pohon lengkap, yang terakumulasi selama ribuan tahun. Lapisan gambut terbentuk karena tumbuhan yang mati dalam keadaan normal dengan cepat mengalami penguraian oleh bakteri dan organisme lainnya. Namun karena sifat tanah gambut yang anaerob dan memiliki keasaman tinggi, serta kurangnya unsur hara, maka proses dekomposisi berlangsung lambat (Utomo, 2008). Menurut Agus et al. (2011), hutan gambut yang masih alami berperan sebagai penyerap gas $\mathrm{CO} 2$ dan menyimpan cadangan air. Tanah gambut memiliki cadangan karbon dalam tanah sebesar 300$700 \mathrm{t} / \mathrm{ha}$.

Indonesia memiliki areal gambut terluas di zona tropis, diperkirakan mencapai 21 juta ha, mempresentasekan $70 \%$ areal gambut di Asia Tenggara dan $50 \%$ dari lahan gambut tropis di dunia (Wibowo, 2009). Lahan gambut Indonesia terpusat di tiga pulau besar yaitu Sumatra (35\%), Kalimantan (32\%), Papua (30\%), dan pulau lainnya (3\%) dengan total luas 21 juta ha (Wahyunto \& Heryanto, 2005). Menurut Wahyunto dan Subiksa (2011), lahan gambut di Indonesia tersebar mulai dari daerah dataran rendah hingga daerah dataran tinggi.

Pemanfaatan lahan gambut mendapat perhatian besar, terutama untuk budidaya tanaman perkebunan. Selain itu lahan gambut juga berpotensi besar untuk budidaya tanaman pangan (Utama\&Haryoko, 2009). Sedangkan menurut Sagiman (2007) pengembangan lahan gambut untuk pertanian tidak hanya ditentukan oleh sifat-sifat fisika maupun kimia gambut, namun dipengaruhi pula oleh manajemen usaha tani yang akan diterapkan. 
Sifat fisika tanah merupakan kunci penentu kualitas suatu lahan dan lingkungan. Lahan dengan sifat fisika yang baik akan memberikan kualitas lingkungan yang baik juga. Sifat fisika tanah diambil sebagai pertimbangan pertama dalam menetapkan suatu lahan untuk pertanian (Yulnafatmawati et al., 2007). Sedangkan menurut Wasis (2005) sifat fisika tanah merupakan komponen yang sangat penting dalam penyediaan sarana tumbuh tanaman dan mempengaruhi kesuburan tanah yang pada akhirnya akan menunjang pertumbuhan, bahkan lebih penting pengaruhnya dibandingkan dengan sifat kimia maupun biologi tanah. Sifat fisika tanah gambut merupakan bagian dari morfologi tanah yang penting peranannya dalam penyediaan sarana tumbuh tanaman (Suswati et al., 2011).

Hutan sekunder yang berada di desa Kualu Nenas Kecamata Tambang Kabupaten Kampar Provinsi Riau merupakan bagian dari kebun percobaan Fakultas Pertanian dan Peternakan UIN Syarif Kasim Riau. Kondisi yang belum pernah diolah sebagai lahan pertanian. Oleh karena itu diperlukan kajian untuk mengetahui status kesuburan tanah tersebut. Berdasarkan keterangan di atas, maka penulis tertarik melakukan penelitian dengan judul "Analisis Sifat Fisika Tanah Gambut Pada Hutan Sekunder di Kecamatan Tambang Kabupaten Kampar Provinsi Riau".

\section{BAHAN DAN METODE}

Penelitian ini telah dilaksanakan pada bulan Januari sampai April 2013. Lokasi penelitian terletak di Desa Kualu Kualu Nenas (1010 14'-43,7" BT dan 00 26'-14,6" LU), Kecamatan Tambang, Kabupaten Kampar, Provinsi Riau. Lokasi penelitian memiliki luas \pm 21 ha, dengan topografi datar dengan lereng $0 \%$, dan terletak pada ketinggian $4 \mathrm{~m}$ dpl. Pengambilan sampel dilakukan di hutan gambut sekunder dengan menggunakan metode proposive random sampling terdiri dari 4 titik sampel dengan kedalaman $0-50 \mathrm{~cm}, 50-$ $100 \mathrm{~cm}$, dan 100-150 cm.

Metode analisis kedalaman muka air tanah $(\mathrm{cm})$ dan kedalaman gambut $(\mathrm{cm})$ dengan pengeboran langsung dilapangan. Warna tanah gambut diamati dengan Munsel Soil Chart, kematangan gambut dengan perbandingan jumlah serat, sedangkan bobot isi $(\mathrm{gr} / \mathrm{cm} 3)$ dan kadar air (\%) menggunakan metode gravimetric.

\section{HASIL DAN PEMBAHASAN}

Hutan gambut sekunder adalah hutan gambut yang telah mengalami penebangan atau hutan bekas tebang sehingga potensinya menurun dan telah menunjukan adanya perbedaan dengan jenis alami hutan sebelumnya. Hutan gambut sekunder yang telah mengalami tekanan yang lebih lanjut potensi vegetasinya sangat sedikit (Rochamayanto et al., 2010). Lokasi penelitian merupakan lahan gambut yang pernah mengalami kebakaran dan telah memiliki saluran drainase bagian depan (timur) dengan ukuran lebar dan kedalaman $2 \mathrm{~m}$. Selain itu pada bagian belakang (barat) dengan lebar 3 $\mathrm{m}$ dan kedalaman 2,5 m. Pada hutan gambut sekunder ditumbuhi vegetasi jenis pohon antara lain tenggek burung (Eudodia redleyi), mahang (Macarana inflolucrata), pulai (Alstonia sp), pada semak belukar didominasi paku-pakuan (Pteridophyta), sedangkan tanaman rendah ditumbuhi jenis kantong semar (Nepenthes sp) dan tanaman jenis anggrek (Dendrobium sp).

\section{Ketebalan Gambut}

Lokasi penelitian memiliki ketebalan gambut > $6 \mathrm{~m}$ (Tabel 1). Ini merupakan golongan gambut sangat dalam sehingga pada lahan gambut yang memiliki kedalaman gambut sedemikian rupa tidak cocok untuk dikonversi menjadi lahan pertanian, baik itu tanaman tahunan maupun tanaman lainnya karena gambut ini tergolong tidak sesuai permanen (kelas N). Gambut dengan ketebalan > $3 \mathrm{~m}$ diperuntukan sebagai kawasan konservasi sesuai dengan keputusan presiden No. 32/1990. Hal ini disebabkan oleh semakin tebal gambut, semakin penting pula fungsinya dalam memberikan perlindungan terhadap lingkungan dan sebaliknya kondisi lingkungan lahan gambut tebal semakin rapuh apabila dikonversi menjadi lahan pertanian. Pertanian di lahan gambut tebal lebih sulit pengelolaannya dan mahal biayanya karena kesuburannya rendah dan daya dukung tanahnya rendah sehingga sulit dilalui kendaraan pengangkutan sarana pertanian dan hasil panen (Agus \& Subiksa, 2008).

Semakin tebal lapisan gambut maka kesuburan tanahnya semakin menurun sehingga tanaman sulit mencapai lapisan mineral yang berada di lapisan bawahnya. Hal ini mengakibatkan pertumbuhan tanaman terganggu, serta mengakibatkan tanaman mudah condong dan roboh khususnya pada tanaman tahunan atau tanaman perkebunan (Suswati et al., 2011) 
Berdasarkan tingkat kesuburannya lokasi penelitian tergolong gambut oligotropik atau gambut yang tidak subur dan terdiri dari gambut ombrogen. Gambut oligotrofik adalah gambut yang mengandung sedikit mineral, khususnya kalsium dan magnesium, serta bersifat asam atau sangat asam $(\mathrm{pH}<4,5)$, termasuk gambut miskin hara dan umumnya mempunyai ketebalan $>2 \mathrm{~m}$ dan hanya mendapat sumbangan hara dari air hujan dan perombakan bahan organik setempat (Soekardi \& Hidayat, 1998).

Citra lanskap yang mengukur berdasarkan rona penampakan pola sungai, elevasi, dan lereng maka lokasi penelitian merupakan kawasan lindung kubah gambut (KLG). Kubah gambut adalah bagian dari ekosistem gambut yang cembung dan memiliki elevasi lebih tinggi dari daerah sekitarnya, yang berfungsi sebagai pengatur keseimbangan air. Kubah gambut yang terletak di sekitar titik tengah puncak kubah gambut yang luasnya minimal $30 \%$ dari seluruh areal kesatuan hidrologis gambut (Kementerian Negara Lingkungan Hidup Riau, 2010).

Tabel 1. Ketebalan dan Kedalaman Muka Air Tanah Gambut

\begin{tabular}{cccccc}
\hline & \multirow{2}{*}{ Tit } & \multicolumn{2}{c}{ Ketebalan Gambut } & \multicolumn{2}{c}{$\begin{array}{c}\text { Kedalaman } \\
\text { Muka Air Tanah }\end{array}$} \\
\cline { 3 - 6 } & ik & $\mathbf{( c m )}$ & Kategori & $\mathbf{( c m )}$ & Kategori \\
\hline 1 & I & $>600$ & Sangat dalam & $>600$ & Sangat dalam \\
2 & II & $>600$ & Sangat dalam & $>600$ & Sangat dalam \\
3 & III & $>600$ & Sangat dalam & $>600$ & Sangat dalam \\
4 & IV & $>600$ & Sangat dalam & $>600$ & Sangat dalam \\
\hline
\end{tabular}

Sumber: Hasil analisis di lapangan (2013).

\section{Kedalaman Muka Air Tanah}

Kedalaman muka air tanah dari permukaan tanah memiliki kedalaman mulai dari $23 \mathrm{~cm}$ sampai $38 \mathrm{~cm}$. Pada titik 1 memiliki kedalaman muka air tanah $(38 \mathrm{~cm})$, titik $2(29$ $\mathrm{cm})$, titik $3(23 \mathrm{~cm})$, dan titik $4(33 \mathrm{~cm})$. Penurunan muka air tanah terlihat pada titik 1 $(38 \mathrm{~cm})$ dan titik $4(33 \mathrm{~cm})$, pada jarak 100-400 $\mathrm{m}$ dan 400-100 m dari saluran drainase (Tabel 1). Dari hasil pengamatan di lapangan, diketahui bahwa muka air tanah semakin dekat dari saluran drainase, maka permukaan air tanah akan semakin dalam. Hal ini disebabkan oleh pergerakan air tanah semakin tinggi, sehingga terjadi pengurangan kadar air tanah gambut akibat pengeringan, yang menyebabkan daya retensi air tanah berkurang, pembuatan saluran drainase sangat mempengaruhi penurunan muka air tanah gambut (Azri, 1999).

Kondisi muka air tanah gambut selain dipengaruhi oleh pembukaan saluran drainase juga dipengaruhi oleh factor iklim, terutama curah hujan. Ketinggian muka air tanah akan mempengaruhi kematangan dan dekomposisi tanah gambut. Sebagaimana disebutkan oleh Las et al. (2008) bahwa pengaturan tata air makro maupun tata air mikro sangat mempengaruhi karakteristik lahan gambut. Tinggi muka air tanah akan mempengaruhi dekomposisi gambut (subsiden) dan kering tak balik (irreversibel drying).

\section{Warna Tanah}

Warna tanah gambut pada setiap titik pengamatan lapisan paling atas memiliki warna lebih gelap dari pada lapisan bagian bawahnya, yakni pada kedalaman $0-29 \mathrm{~cm}$ (titik 1), 0-22 cm (titik 2), 0-25 cm (titik 3), 0-26 $\mathrm{cm}$ (titik 4), dengan warna $10 \mathrm{R} 2,5 / 1$ atau hitam kemerahan (Tabel 2). Ini dikarenakan bagian atas gambut telah mengalami kebakaran. Sedangkan pada lapisan bawahnya tanah mengalami perubahan agak terang, pada kedalaman 29-64 cm (titik 1), 22$51 \mathrm{~cm}$ (titik 2), $25-53 \mathrm{~cm}$ (titik 3), 26-60 cm (titik 4), dengan warna $10 R 2,5 / 2$ atau merah sangat kusam. Tetapi pada lapisan paling bawah, tanah mengalami perubahan menjadi agak gelap, pada kedalama $64-119 \mathrm{~cm}$ (titik 1), 51-110 cm (titik 2), 53-105 cm (titik 3), 60-100 $\mathrm{cm}$ (titik 4), dengan warna 5 YR $3 / 2$ atau coklat kemerahan gelap, dan pada lapisan lebih dari 1 meter tanah mengalami perubahan warna menjadi lebih gelap, pada kedalaman 119-150 $\mathrm{cm}$ (titik 1), 110-150 cm (titik 2), 105-150 cm (titik 3), 100-150 cm (titik 4), dengan warna 10 YR $2 / 1$ atau coklat kehitaman. Hal ini dikarenakan pada lapisan paling bawah, tanah masih memiliki kandungan bahan organik sangat tinggi.

Tabel 2. Warna Tanah Gambut

\begin{tabular}{|c|c|c|c|c|}
\hline No & Titik & $\begin{array}{l}\text { Kedalaman } \\
\text { (cm) }\end{array}$ & $\begin{array}{l}\text { Warna } \\
\text { Tanah }\end{array}$ & Keterangan \\
\hline \multirow{4}{*}{1} & \multirow{4}{*}{ I } & $0-29$ & $10 \mathrm{R} 2,5 / 1$ & Hitam Kemerahan \\
\hline & & $29-64$ & $10 R 2,5 / 2$ & Merah Sangat Kusam \\
\hline & & $64-119$ & 5 YR $3 / 2$ & Coklat kemerahan gelap \\
\hline & & $119-150$ & 10 YR $2 / 1$ & Coklat kehitaman \\
\hline \multirow{4}{*}{2} & \multirow{4}{*}{ II } & $0-22$ & $10 \mathrm{R} 2,5 / 1$ & Hitam Kemerahan \\
\hline & & $22-51$ & $10 R 2,5 / 2$ & Merah Sangat Kusam \\
\hline & & $51-110$ & 5 YR $3 / 2$ & Coklat kemerahan gelap \\
\hline & & $110-150$ & 10 YR 2/1 & Coklat kehitaman \\
\hline \multirow{4}{*}{3} & \multirow{4}{*}{ III } & $0-25$ & $10 \mathrm{R} 2,5 / 1$ & Hitam Kemerahan \\
\hline & & $25-53$ & $10 \mathrm{R} 2,5 / 2$ & Merah Sangat Kusam \\
\hline & & $53-105$ & 5 YR 3/2 & Coklat kemerahan gelap \\
\hline & & $105-150$ & 10 YR 2/1 & Coklat kehitaman \\
\hline \multirow{4}{*}{4} & \multirow{4}{*}{ IV } & $0-26$ & $10 \mathrm{R} 2,5 / 1$ & Hitam Kemerahan \\
\hline & & $26-60$ & $10 R 2,5 / 2$ & Merah Sangat Kusam \\
\hline & & $60-100$ & 5 YR $3 / 2$ & Coklat kemerahan gelap \\
\hline & & $100-150$ & 10 YR $2 / 1$ & Coklat kehitaman \\
\hline
\end{tabular}

Sumber: Hasil analisis dilapangan (2013).

Menurut Suswati et al. (2011), bahwa perbedaan warna tanah pada umumnya disebabkan oleh perbedaan kandungan bahan organik, semakin tinggi bahan organik maka 
warna tanah akan semakin gelap. Darmawijaya (1997) pada umumnya bahan organik memberi warna kelam pada tanah, artinya jika tanah asalnya berwarna kuning atau coklat muda, kandungan bahan organik menyebabkan warna lebih cenderung kearah coklat kelam. Makin stabil bahan organik makin tua warnanya, sedangkan makin segar maka makin cerah warnanya.

\section{KematanganGambut (Kadar Serat \%)}

Kematangan gambut pada lahan hutan sekunder (titik I, II, II, dan IV) terdiri dari tingkat kematangan fibrik dan hemik. Gambut memiliki kematangan fibrik apabila V2/V1> 66\%, hemik apabila V2/V1 antara 33\%-66\%, dan saprik apabila V2/V1<33\%. Pada masing-masing kedalaman memiliki kadar serat yang berbeda pada setiap titiknya, tetapi pada kedalaman yang sama pada setiap titik yang berbeda memiliki kadar serat yang hampir sama dan memiliki kematangan gambut yang sama. Pada kedalaman $0-50 \mathrm{~cm}$ memiliki kadar serat $38 \%$ - $44 \%$ tergolong gambut hemik, pada kedalaman 50-100 cm memiliki kadar kadar serat $59 \%-63 \%$ tergolong gambut hemik, sedangkan pada kedalaman 100-150 cm memiliki kadar serat $67 \%-74 \%$ tergolong gambut fibrik. Kandungan kadar serat pada masing-masing titik dan kedalaman bisa dilihat pada Tabel 3.

Secara umum tingkat dekomposisi pada lapisan gambut pada lapisan atas dan di atas muka air tanah lebih tinggi atau lebih lanjut daripada lapisan gambut di bawah muka air tanah. Berdasarkan penilaian terhadap perubahan kematangan gambut, maka secara ekologis yang menjadi faktor utama yang mempengaruhi adalah tinggi muka air tanah (water level) (Suwondo et al., 2010).

\section{Bobot Isi (BD)}

Nilai bobot isi pada masing-masing titik pengamatan diukur disetiap kedalaman $50 \mathrm{~cm}$. Pada kedalaman $0-50 \mathrm{~cm}$ memiliki bobot isi berkisar 0,16 $\mathrm{gr} / \mathrm{cm} 3-0,14 \mathrm{gr} / \mathrm{cm} 3$. Pada kedalaman $50-100 \mathrm{~cm}$ memiliki bobot isi berkisar antara 0,14 gr/cm3 - 0,11 gr/cm3, dan pada kedalaman $100-150 \mathrm{~cm}$ memiliki bobot isi berkisar antara 0,11 gr/cm3-0,09 gr/cm3 (Tabel 3). Pada kedalaman yang berbeda menghasilkan nilai bobot isi sangat bervariasi, disebabkan oleh perbedaan tingkat kematangan gambut, terjadinya pemadatan.

Kedalaman 0-50 cm cenderung memberikan respon nilai bobot isi terbesar $0,16 \mathrm{gr} / \mathrm{cm} 3$ (titik 1), 0,15 gr/cm3 (titik 2 dan 4), $0,14 \mathrm{gr} / \mathrm{cm} 3$ (titik 3 ), dengan nilai rata-rata 0,15 gr/cm3. Berbeda dengan kedalaman 50 - 100 $\mathrm{cm}$ nilai bobot isi $0,14 \mathrm{gr} / \mathrm{cm} 3$ (titik 1), 0,12 gr/cm3 (titik 2), 0,11 gr/cm3 (titik 3), 0,13 $\mathrm{gr} / \mathrm{cm} 3$ (titik 4) dengan nilai bobot isi rata-rata $0,125 \mathrm{gr} / \mathrm{cm} 3$. Respon nilai bobot isi paling kecil terjadi pada kedalaman $100-150 \mathrm{~cm}$ yaitu sebesar $0,11 \mathrm{gr} / \mathrm{cm} 3$ (titik 1, 2, dan 4) sedangkan 0,09 gr/cm3 (titik 3), dengan nilai bobot isi rata-rata $0,105 \mathrm{gr} / \mathrm{cm} 3$. Hal tersebut menunjukkan bahwa makin dalam lapisan tanah maka nilai bobot isi menjadi semakin rendah atau dengan kata lain kedalaman tanah yang lebih dalam menunjukkan kondisi bobot isi yang cenderung lebih rendah (Noor 2001). Proses dekomposisi yang terjadi pada tiap kedalaman berbeda-beda. Nilai bobot isi yang rendah diakibatkan oleh adanya rongga pada gambut yang dipengaruhi oleh adanya akar-akar tumbuhan maupun dari kayu pepohonan. Nilai bobot isi yang tinggi diakibatkan oleh terjadinya pemadatan dan pengaruh lapisan liat (Batubara, 2009).

Menurut Hardjowigeno (1989) nilai bobot isi menunjukan tingkat kepadatan tanah, semakin tinggi nilai bobot isi maka semakin padat suatu tanah dan sebaliknya. Sedangkan menurut Subagyono et al. (1997) tanah gambut memiliki bobot isi yang rendah antara 0,05-0,25 gr/cm3, semakin rendah nilai bobot isi maka tingkat dekomposisinya semakin lemah, atau kematangan gambutnya semakin rendah, karena masih banyak mengandung bahan organik. Sehingga daya tompang terhadap beban diatasnya seperti tanaman, bangunan irigasi, jalan, dan mesin-mesin pertanian adalah rendah. Sedangkan gambut yang sudah direklamasi akan lebih padat dengan bobot isi antara 0,1-0,4 gr/cm3. Selanjutnya Noor (2001), menyatakan bahwa bobot isi gambut yang rendah mengakibatkan daya dukung tanah rendah sehingga tanaman mengalami kendala dalam menjangkarkan akarnya, akibatnya banyak tanaman tahunan yang tumbuh condong dan tumbang.

\section{Kadar Air}

Tanah gambut mempunyai kapasitas mengikat atau memegang air yang relatif sangat tinggi atas dasar berat kering. Kapasitas mengikat air maksimum untuk gambut fibrik adalah 580-3000\%, untuk gambut hemik $450-850 \%$ dan untuk gambut saprik < $450 \%$ (Tabel 3). Gambut akan berubah menjadi hidrofob (menolak air) kalau terlalu kering.

Pada kedalaman $0-50 \mathrm{~cm}$ memiliki kadar air berkisar 442,80 \% - 655,61\%. Pada kedalaman 50-100 cm memiliki kadar air berkisar antara 626,20 \% - 872,55 \%, dan pada kedalaman 100-150 cm memiliki bobot isi berkisar antara 815,11 \% - 1020,59 \%. Pada 
setiap kedalaman dan masing-masing titik nilai kadar airnya bervariasi (Tabel 3).

Tabel 3. Kematangan Gambut, Bobot Isi, dan

\begin{tabular}{|c|c|c|c|c|c|}
\hline No & Titik & Kedalaman & $\begin{array}{c}\text { Kematangan } \\
\text { gambut }\end{array}$ & $\begin{array}{l}\text { Bobot isi } \\
\left(\mathrm{gr} / \mathrm{cm}^{3}\right)\end{array}$ & $\begin{array}{c}\text { Kadar Air } \\
(\%)\end{array}$ \\
\hline & & $0-50$ & Hemik & 0,16 & 474,52 \\
\hline \multirow[t]{2}{*}{1} & 1 & $50-100$ & Hemik & 0,14 & 626,20 \\
\hline & & $100-150$ & Fibrik & 0,11 & 888,87 \\
\hline \multirow{3}{*}{2} & & $0-50$ & Hemik & 0,15 & 442,80 \\
\hline & II & $50-100$ & Hemik & 0,12 & 687,87 \\
\hline & & $100-150$ & Fibrik & 0,11 & 815,11 \\
\hline \multirow{3}{*}{3} & & $0-50$ & Hemik & 0,14 & 655,61 \\
\hline & III & $50-100$ & Hemik & 0,11 & 872,55 \\
\hline & & $100-150$ & Fibrik & 0,09 & 1020,59 \\
\hline \multirow{3}{*}{4} & & $0-50$ & Hemik & 0,15 & 594,37 \\
\hline & IV & $50-100$ & Hemik & 0,13 & 691,02 \\
\hline & & $100-150$ & Fibrik & 0,11 & 828,61 \\
\hline
\end{tabular}

Sumber: Hasil analisis dilaboratorium (2013).

Kadar air tanah pada kedalaman 100$150 \mathrm{~cm}$ memiliki kadar yang lebih besar dibandingkan dengan kadar air tanah pada kedalaman 50-100 cm. Sedangkan kadar air tanah terendah adalah pada kedalaman 0-50 $\mathrm{cm}$. Jadi kedalaman solum atau lapisan tanah menentukan volume simpan air tanah, semakin dalam suatu lapisan tanah maka kadar air tanah semakin tinggi. Ini disebabkan semakin dalam lapisan tanah maka kematangan gambut semakin rendah, sehingga tanah mampu memegang air lebih banyak. Noor (2001) menyebutkan bahwa kemampuan menjerap (absorbing) dan memegang (retaining) air dari gambut tergantung pada tingkat kematangannya. Kemampuan tanah gambut untuk menyerap dan mengikat air pada gambut fibrik lebih besar dari gambut hemik dan saprik, sedangkan gambut hemik lebih besar dari saprik (Suwondo et al., 2010).

Sedangkan menurut Saribun (2007), ketersediaan air tanah bukan hanya berdasarkan kematangannya saja, tetapi dipengaruhi juga oleh curah hujan atau air irigasi, kemampuan tanah menahan air, evapotranspirasi, dan tinggi muka air tanah. Kadar air selain dipengaruhi oleh disebabkan oleh kepadatan tanah, karena tanah akan lebih sedikit memegang air (Mardina, 2006).

\section{KESIMPULAN DAN SARAN}

\section{Kesimpulan}

1. Tanah gambut di Desa Kualu Nenas Kecamatan Tambang Kabupaten Kampar Provinsi Riau, memiliki kedalaman gambut lebih dari 6 meter, dengan kedalaman muka air tanah rata-rata $30,75 \mathrm{~cm}$, dan memiliki warna tanah hitam kemerahan, merah sangat kusam, dan coklat kehitaman.
2. Memiliki kematangan gambut pada kedalaman 0-50 cm dan 50-100 cm tergolong gambut hemik dengan kadar serat masing-masing $41 \%$ dan $61 \%$, sedangkan kedalaman 100-150 cm tergolong gambut fibrik (kadar serat $70,25 \%$ ). Bobot isi (BD) pada kedalaman 0-

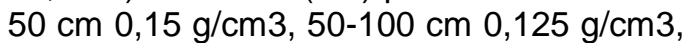
dan 100-150 cm 0,105 g/cm3, kadar air pada kedalaman 0-50 cm 541,82 \%, 50-100 cm 719,41\%, dan 100-150 cm 888,30\%.

\section{DAFTAR PUSTAKA}

Arifin, M. 2010. Kajian Sifat Fisik Tanah dan Berbagai Penggunaan Lahan Dalam Hubungannya Dengan Pendugaan Erosi Tanah. Jurnal Pertanian MAPETA, 12 (2): $72-144$

Agus, F., K. Hiriah, dan A. Mulyani. 2011. Pengukuran Cadangan Karbon. Balai Penelitian Tanah. Bogor. 57 hal.

Azri. 1999. Sifat kering Tidak Balik Tanah Gambut dari Jambi dan Kalimantan Tengah: Analisis Berdasarkan Kadar Air Kritis, Kemasaman Total, Gugus Fungsional $\mathrm{COOH}$ dan $\mathrm{OH}$-Phenolat. Tesis. Pogram Pascasarjana. Institut Pertanian Bogor.76 hal.

Agus, F. dan Subiksa I.G.M. 2008. Lahan Gambut: Potensi Untuk Pertanian dan Aspek Lingkungan. Balai Penelitian Tanah. Bogor. 36 hal.

Batubara, S.F. 2009. Pendugaan Cadangan Karbon dan Emisi Gas Rumah Kaca Pada Tanah Gambut di Hutan dan Semak Belukar yang Telah Didrainase. Tesis. Pogram Pascasarjana. Institut Pertanian Bogor.64 hal.

Darmawijaya, M.I. 1997. Klasifikasi Tanah, Dasar Teori Bagi Peneliti Tanah dan Pelaksanaan Pertanian Indonesia. Universitas Gadjah Mada Press, Yogyakarta. 19 hal.

Hardjowigeno. S. 1986. Sumber Daya Fisik Wilayah dan Tata Guna Lahan Histosol. Fakultas Pertanian Institut Pertanian Bogor.

Kementerian Negara Lingkungan Hidup. 2010. Masterplan Pengelolaan Ekosistem Gambut Provinsi Riau. 35 hal.

Las, I., K. Nugroho, dan A. Hidayat.2008. Strategi Pemanfaatan Lahan Gambut untuk Pengembangan Pertanian Berkelanjutan. Jurnal Pengembangan Inovasi Pertanian, 2(4): 295-298.

Mardiana, S. 2006. Perubahan Sifat-Sifat Tanah pada Kegiatan Konversi Hutan Alam Rawa Gambut Menjadi 
Perkebunan Kelapa Sawit. Skripsi. Fakultas Kehutanan IPB. Bogor. 41 hal.

Noor, M. 2001. Pertanian Lahan Gambut (Potensi dan Kendala). Kanisus. Yogyakarta.

Rochmayanto, Y., D. Darusaman, dan T. Rusolono. 2010. Perubahan Kandungan Karbon dan Nilai Ekonominya pada Konversi Hutan Rawa Gambut Menjadi Tanaman Industri Pulp. Jurnal Tanaman Hutan, 7(2):93-106.

Sagiman, S. 2007. Pemanfaatan Lahan Gambut dengan Perspektif Pertanian Berkelanjutan. Fakultas Pertanian Universitas Tanjungpura. Pontianak. $32 \mathrm{hal}$.

Saribun. 2007. Pengaruh Jenis Penggunaan Lahan dan Kelas Kemiringan Lereng Terhadap Bobot Isi, Porositas Total, dan Kadar Air Tanah pada Sub-DAS Cikapundung Hulu. Skripsi. Jurusan IImu Tanah. Fakultas Pertanian. Universitas Padjajaran. 61 hal.

Soekardi M, Hidayat A. 1988. "Extent and Distribution of Peat Soils of Indonesia". In.: Paper Presented at Third Meeting of the CooperativeResearch on Problem Soils. Bogor, on Agust 22 - 26, 1988.

Subagyono, K., T. Vadari., dan I.P.G. WidjajaAdhi. 1997. Strategi Pengelolaan Air dan Tanah pada Lahan Rawa pasang Surut : Prospek dan Kendala. Makalah disampaikan pada Pertemuan Pembahasan dan Komunikasi Hasil Penelitian Tanah dan Agroklimat Tanggal $4 \mathrm{~s} / \mathrm{d} 6$ Maret.

Suswati, D., B. Hendro, D. Shiddieq, dan D. Indradewa.2011. Identifikasi Sifat Fisik Lahan Gambut Rasau Jaya III
Kabupaten Kubu Raya Untuk Pengembangan Jagung. Jurnal Perkebunan dan Lahan Tropika, 1: 3140.

Suwondo, S., Sabiham., Sumardjo., dan B. Paramudya.2011. Efek Pembukaan Lahan terhadap karakteristik Biofisik Gambut pada Perkebunan Kelapa Sawit di Kabupaten Bengkalis. Jurnal Natur Indonesia, 14 (2): 143-149.

Utama, M.Z.H. dan W. Haryoko. 2009. Pengujian Empat Varietas Padi Unggul pada Sawah Gambut Bukaan Baru di Kabupaten Padang Pariaman. Jurnal Akta Agrosia, 12 (1): 56 - 61.

Wasis, B. 2005. Kajian Perbandingan Kualitas Tempat Tumbuhan Antara Rotasi Pertama dan Rotasi Kedua Pada Hutan Tanaman Acacia mangium Willd.Studi Kasus di HTI Musi Hutan Persada, Provinsi Sumatra Selatan. Disertasi. Sekolah Pascasarjana. Institut Pertanian Bogor.92 hal.

Wahyunto dan I.G.M. Subiksa. 2011. Pengelolaan Lahan gambut Indonesia. Balai penelitian Tanah. Bogor.

Wahyunto dan B. Heryanto. 2005. Sebaran Gambut dan Status Terkini di Sumatera. In.CCFPI. Pemanfaatan Lahan Gambut Secara Bijaksana Untuk Manfaat Berkelanjutan. Pekanbaru. Wetlands International-Indonesia Programe. Bogor.

Yulnafatmawati, U., Luki, dan A. Yana. 2007. Kajian Sifat Fisika Tanah Beberapa Penggunaan Lahan di Bukit Gajabuih Kawasan Hutan Hujan Tropik Gunung Gadut Padang. Jurnal Solum, 4 (2): 4961. 


\section{J U R N A L AGROTEKNOLOGI Journal of Agrotechnology}

PENGARUH PEMBERIAN PUPUK KALIUM DAN CAMPURAN KOMPOS TANDAN KOSONG KELAPA SAWIT DENGAN ABU BOILER TERHADAP PERTUMBUHAN DAN HASIL TANAMAN BAWANG MERAH (Allium asacalonicum L.)

The Effect of Potassium Fertilizer and Compost Mixture of Oil Palm Empty Bunches with Boiler Ash on Growth and Yield of Onion (Allium ascalonicum L.)

Dian Fikri Alfian, Nelvia, Husna Yetti

DAMPAK PERKEBUNAN KELAPA SAWIT TERHADAP PEREKONOMIAN WILAYAH DI KABUPATEN ROKAN HULU

The Impact of Palm Plantation Development in the Economic Region in Rokan Hulu district Irsyadi Siradjuddin

OPTIMASI METODE ISOLASI DNA PADA Jatropha spp.

Optimation of DNA Isolation Method on Jatropha spp.

Kristianto Nugroho, Rerenstradika T. Terryana, dan Puji Lestari

ANALISIS SIFAT FISIKA TANAH GAMBUT PADA HUTAN GAMBUT DI KECAMATAN TAMBANG KABUPATEN KAMPAR PROVINSI RIAU

Analysis of Soil Physical Peat Land in Peat Forests in Tambang Sub-District, Kampar District, Riau Province

Susandi, Oksana, dan Ahmad Taufiq Arminudin

OPTIMASI NAA DAN BAP TERHADAP PERTUMBUHAN DAN PERKEMBANGAN TUNAS MIKRO TANAMAN KANTONG SEMAR (Nepenthes mirabilis) SECARA IN VITRO

Optimize Of NAA And BAP On Growth And Development Of Micro Shoots Pitcher Plant (Nepenthes Mirabilis)Through In Vitro

Rosmaina dan Dinni Aryani

APLIKASI PUPUK KANDANG SAPI DAN AYAM TERHADAP PERTUMBUHAN DAN HASIL TANAMAN JAHE (Zingiber officinale Rosc.) DI MEDIA GAMBUT

The Application of Cattle Chicken Manures With Different Dosages on The Growth and Yield of Ginger (Zingiber officinale Rosc.) in Peat Media

Yuliana, Elfi Rahmadani, dan Indah Permanasari 